\title{
CALVING INTERVAL OF PRODUCTIVE PC TO INCREASE CATTLE POPULATION GROWTH: A CASE STUDY AT SOUTH SULAWESI, INDONESIA
}

\author{
Muhammad Basir Paly ${ }^{1}$ \\ ${ }^{1}$ Department of Animal Science, Faculty of Science and Technology, Alauddin Makassar State Islamic University, \\ Jl. Sultan Alauddin No.63, Romangpolong, Kec. Somba Opu, Kabupaten Gowa, Sulawesi Selatan 92113, Indonesia
}

To link to this article: https://doi.org/10.11118/actaun201967051325

Received: 7. 4. 2018, Accepted: 16. 10. 2019

To cite this article: PALY MUHAMMAD BASIR. 2019. Calving Interval of Productive PC to Increase Cattle Population Growth: A Case Study At South Sulawesi, Indonesia. Acta Universitatis Agriculturae et Silviculturae Mendelianae Brunensis, 67(5): 1325-1333.

\begin{abstract}
This study aimed to determine the contribution of shortening the calving interval to the growth of the beef cattle population in Indonesia. It used panel data from the 2013-2016 time series and crosssectional data from 24 districts in South Sulawesi. The variables observed were population growth (PG), productive cows (PC) which have the potential to give birth and calving interval (CI). The data were analyzed by regression of panel data using software-reviews 8 . The results showed an average length of CI of 28.18 months. PC gave a positive contribution of 0.003\% to PG but was not significant ( $p>0.05$ ), while CI contributed negatively to PG by $-0.028 \%$ and was significantly $(p<0.05)$ for PG. A $1 \%$ increase in CI could decrease PG by $0.028 \%$. On the contrary, any decreased or shortening by $1 \%$ of CI could raise PG by $0.028 \%$. Without shortening CI, PG decrease. The shortening of the calving interval on the growth of the beef cattle population in Indonesia can be done by up to $45 \%$, from $28.18 \pm 4.12$ to $15.15 \pm 4.12$ months and PG increased about $1.311 \%$ from $5.633 \%$ to $6.944 \%$. The key to shortening $\mathrm{CI}$ is a change of maintenance system, from extensive to semi-intensive, and control of the mating process. Breeders should limit the length of the weaning period and maximize conceptions during the mating period.
\end{abstract}

Keywords: beef cattle, calving interval, population, productive cow

\section{INTRODUCTION}

The effort to increase the growth of the beef cattle population in Indonesia is becoming a very important issue. In the last three years (20132016) Indonesia's beef cattle population grew by only 838,193 , having an average growth of $6.17 \%$ per year from 12,739,789 to 16,092,561 (BPSb, 2016). The total population of ready stock, there are about 2.3 million beef cattle, or $14.30 \%$ (BPS, 2016a). The Indonesian cow is relatively small as its meat weighs about $150 \mathrm{~kg}$ per cow. From 2.3 million beef cattle, the fresh meat produced is about 345 thousand tons, while the average domestic demand is 465 thousand tons per year. Thus, the Indonesian stock of beef cattle is still short by about 125 thousands ton, which is equivalent to 802 thousands beef cattle. In other words, the total requirement for readily cut beef cattle (ready stock beef cattle) has now increased to 3.102 million per year.

In 2020, the population in Indonesia is projected to be 280 million people and the consumption of beef will be rising, on average by $3 \mathrm{~kg}$ per capita per year (BPS (2016c). When the need for meat reaches 840 thousand ton per year, equivalent to 5.6 million subtracted from the 2.3 million ready-stock beef cattle, then Indonesia still has to find an additional 3.3 million more. Therefore, efforts related to the increase of the domestic cattle population are urgently required. 
Two main programs have been intensively promoted by the Indonesian Agriculture Ministry concerning the efforts to increase the population growth, they are called the Productive Cow (PC) protection program and the Artificial Insemination (AI) program. PC protection is supported by Law No. 41 of 2014, particularly in article 18 paragraph (4) which states; "Whoever slaughters a PC, is sentenced to imprisonment of at least 1 (one) year and a maximum of 3 (three) years and a fine of at least IDR 100,000,000 (one hundred million rupiah) and at most IDR 300,000,000 (three hundred million rupiah)” (UURI, 2014). PC here refers to an adult female cow 2 to 7 years old. PC older than that age range is categorized as non-productive and they can be sold for meat consumption. The goal is to keep PCs maintained for calves. Nevertheless, PC slaughter is still conducted at slaughter houses in Indonesia (Rasminati et al., 2010; Soejosopoetro, 2011; Suardana et al., 2013; Wiguna et al., 2015).

The AI program that has been running since 1980 and has only been realized for 30-35\% of the potential acceptors. Potential acceptors refer to the PCs that are ready for AI. Hence, the issue around the growth of the beef cattle population in Indonesia remains (Ifar and Bambang, 2010; Priyanto, 2011). The common indicators used to measure AI success relate more to the productivity of the parent cattle individually, not to the broader interests such as population growth. In addition, AI programs can only be performed on intensively maintained PCs. Difficulties appear in operating a 'semi-full extensive' maintenance system, which is still common in many parts of Indonesia such as in South Sulawesi. Nonetheless, it is appreciated that PC protection programs and AI programs have promoted population growth, but they have not yet analyzed the CI. CI is the interval of days or months needed for a cow to give birth in each breeding.

CI-related studies have, at least, been done on beef cattle and dairy cattle in different countries (Sada, 1968; Flores, 1971; Bourdon and Brinks, 1983; Larsson and Berglund, 2008; Grossi et al., 2016). CI is assumed to be one of the growth factors in meat and milk production. A large number of PCs do not necessarily contribute to PG without CI roles. They define CI as the time period used, in lunar units, from the first birth to the next birth.

The number of PC in Indonesia in the last four years (2013-2016) is about 6.7 million (LAHeS, 2015). If the CI period is 12 months, then every year the population will increase by as much as the number of PC, i.e. 6.7 million. If the CI takes 24 months (2 years), then the population grows as little as quarterly from 6.7 million, or 3.35 million, respectively, not 838,193 beef cattle per year as reported (BPS, 2016b). This phenomenon showed that the period of the CI of each PC in Indonesia is relatively long, above 2 years, contributing less sufficiently to PG. Vietnam has been successfully shortened CI from 18.06 to 12.80 months by integrating the preservation system which supplies forages for cows (Huyen et al., 2011). Meanwhile Thailand has another method to shorten CI from 17.19 to 12.17 months by re-breeding PC in the day of 80-86 after giving birth. The re-breeding is AI (Bunmee et al., 2018). These countries have similar agroecosystem and non-intensive preservation with Indonesia but have different methods to shorten CI. In this regard, the study aims to analyze 'the contribution of shortening the CI to the growth of the beef cattle population in Indonesia'.

\section{MATERIALS AND METHODS}

The study was conducted in South Sulawesi Province in October-December 2016. South Sulawesi has a population of about 2 million cattle and was the third-largest cattle population center in Indonesia after East and Central Java (BPS, 2016b).

\section{Data and Variables}

This study used panel data, the combination of time series data and cross-sectional data (Ekananda, 2014). The data time series were used as the data for the last 4 years (2013-2016). The cross-sectional data were collected from 24 districts throughout South Sulawesi, so the data observed was about 96 units. There was an excess of panel data because it involves a greater number of observations. Thus, it increases the degrees of freedom (Gujarati, 2012; Widarjono, 2016). The variables observed in this study were PG in percentage (\%), the number of PC in unit, and the CI in unit of months. PG and PC data were obtained from the Livestock and Animal Health Service Office of South Sulawesi Province, while CI data was obtained from the Livestock/ Agriculture Service in the 24 districts.

\section{Analysis Model}

The data were analyzed by panel data regression using software-reviews 8 based on Sarwono and Hendra's instruction (2014). Panel data has more models than multiple linear regression such as Common Effect (CE), Fixed Effect (FE), and Random Effect (RE). Panel Data does not need to fulfill the classic assumption like Ordinary Least Squared (OLS) in linear regression and able to show the effect of Population Growth (PG). Panel data regression has the same objective as multiple linear regression, i.e. predicting the value of intercept/ constant $\left(\beta_{0}\right)$ and slope $\left(\beta_{1}\right)$. The equation model used for the estimation of $\left(\beta_{0}\right)$ and $\left(\beta_{1}\right)$ is as follows.

$P G_{i t}=\beta_{0}+\beta_{1} P C_{i t}+\beta_{2} C I_{i t}+€_{i t}$,

where:

$P G_{\text {it }}$... dependent variable of population growth,

$\beta_{0}$....... intercept regression,

$P C$.....independent variable of female cattle, CI ......independent variable of calving interval, 
i.........entityn-i,

t........periodn-t,

$€$........residual/error.

Equation (1) can be transformed into a natural logarithm (ln) to modify the units of variables into percentages (\%) (Ekananda, 2014). The In transform is also used to make the estimation model linear, altering the data to be closer to the normal distribution and free of the problem of heteroscedasticity (Widarjono, 2016). The model of the natural logarithmic equation (ln) is as follows:

$\ln P G_{i t}=\beta_{0}+\beta_{1} \ln P C_{i t}+\beta_{2} \ln C I_{i t}+€_{i t}$.

Estimation of the values of $\left(\beta_{0}\right)$ and $\left(\beta_{1}\right)$ can be calculated through three approaches, namely the $\mathrm{CE}, \mathrm{FE}$, and RE models. The CE model, Equation (2), assumes that the data between individuals is equal throughout the observation time, or it ignores the existence of an individual or time-dimensional differences. Meanwhile, the FE model assumes the intercept value of each different district region $\left(\beta_{0 \mathrm{i}}\right)$, while the slope $\left(\beta_{1}\right)$ between regions remains the same. The intercept difference between these regions is denoted by $\left(\beta_{0 \mathrm{i}}\right)$, not $\left(\beta_{0}\right)$, as in Equation (3).

$\ln P G_{i t}=\beta_{0 i}+\beta_{1} \ln P C_{i t}+\beta_{2} \ln C I_{i t}+€_{i t}$

As for the RE model, it assumes that each region has different intercept $\left(\beta_{0}\right)$ as a random or stochastic variable. The value of $\beta_{0 i}$ in this model is no longer fixed (non-stochastic) but is random in nature to be expressed in Equation (4). This RE model also takes into account errors that may be correlated with the cross-section and time series, as shown in (5).

$\ln P G_{i t}=\beta_{0 i}+\beta_{1} \ln P C_{i t}+\beta_{2} \ln C I_{i t}+€_{i t}$,

$\beta_{0 i}=\beta_{0}+\mu_{i}$,

where $\mathrm{i}=1, \ldots, n$; and $\mu_{\mathrm{i}}$ is a random - variable disorder that explains the differences in individual data behavior of districts. The substitution of Equation (3) into (4) yields the following equation:

$$
\begin{aligned}
\ln P G_{i t} & =\beta_{0}+\mu_{1}+\beta_{1} \ln P C_{i t}+\beta_{2} \ln C I_{i t}+€_{i t}= \\
& =\beta_{0}+\beta_{1} \ln P C_{i t}+\beta_{2} \ln C I_{i t}+\left(€_{i t}+\mu_{1}\right) .
\end{aligned}
$$

\section{Model Accuracy Test and Classic Assumption}

To identify the best of these three models (CE, FE, RE), they were tested educing the Chow and Hausman tests and the Lagrange Multiplier (LM) (Ekananda, 2014; Widarjono, 2016). The Chow test is used to select whether the CE or FE model is better by comparing the F-count value at the trust level (a) 0.05. If the cross-section value $\mathrm{F}>0.05$, then the $\mathrm{FE}$ model is better. On the other hand, if $\mathrm{F}<0.05$, then the better model is CE. The Hausman test is used to select the better model between FE or RE with the criterion that if the chi-squared value $>0.05$, then the exact model is RE, but if $<0.05$ then the selected model is FE. The Lagrange Multiplier (LM) test is used to choose whether the CE or RE model is better, with the criterion that if the value of LM (count) $>$ chi-squared at trust level (a) 0.05, then the selected model is RE, if LM < chi-squared then the right model is CE.

Furthermore, to obtain the Best Linear Unreal Estimator (BLUE) estimation result, the RE as the selected model must pass the classical assumption tests. There are five frequently used classical assumption tests (Ekananda, 2014): the linearity test, autocorrelation test, multicollinearity test, normality test, and heteroskedasticity test, all of which are strongly recommended in regression using the ordinary least squares technique (OLS) (Gujarati, 2012; Ekananda, 2014; Widarjono, 2016)

\section{RESULTS}

\section{Estimation Model}

Based on the results of the analysis, the estimation models of the three models of the CE, FE and RE approaches are presented in Tab. I.

Tab. I presents that the intercept (C) models of CE and FE were respectively -2.7839 and -1.9080 but not significant ( $p>0.05$ ), while the RE intercept was

\begin{tabular}{|c|c|c|c|c|c|c|}
\hline \multirow{3}{*}{ Regression statistic } & \multicolumn{6}{|c|}{ Approach Model } \\
\hline & \multicolumn{2}{|c|}{$\mathrm{CE}$} & \multicolumn{2}{|c|}{$\mathrm{FE}$} & \multicolumn{2}{|c|}{$\mathrm{RE}$} \\
\hline & Coef & $\mathrm{p}$-value & Coef & $\mathrm{p}$-value & Coef & $\mathrm{p}$-value \\
\hline Intercept (C) & -2.784 & 0.074 & -1.908 & 0.120 & 5.663 & 0.007 \\
\hline Productive PC (PC) & 0.906 & 0.000 & 0.570 & 0.000 & 0.004 & 0.000 \\
\hline Calving interval (CI) & 0.302 & 0.000 & 0.352 & 0.032 & -0.084 & 0.000 \\
\hline Adjusted R-Squared & 0.622 & - & 0.945 & - & 0.570 & - \\
\hline F-Statistic & 212.292 & - & 273.143 & - & 20.060 & - \\
\hline Prob (F-Statistic) & 0.015 & - & 0.002 & - & 0.010 & - \\
\hline
\end{tabular}

I: The Result of data panel regression of CE, FE and RE approach model

Significant if $\mathrm{p}$-value $<0.05$ 
II: Model accuracy test

\begin{tabular}{lccc}
\hline \multicolumn{1}{c}{ Test } & Value & Prob & Result based on criteria \\
\hline Chow-test & 49.0050 & 0.0000 & FE Model is more accurate than CE model \\
Hausman-test & 1.0113 & 0.6031 & RE Model is more accurate than FE model \\
LM-test & 277.4090 & 0.0188 & RE Model is more accurate than CE model \\
\hline
\end{tabular}

5.6632 and significant $(\mathrm{p}<0.05)$. The PC coefficients in the $\mathrm{CE}, \mathrm{FE}$, and RE models were 0.9064, 0.5754 and 0.0036, respectively, and also significant $(\mathrm{p}<0.05)$. The coefficient of CI for the CE model was 0.3024 ( $p<0.05)$, and for FE of 0.3520 were not significant ( $p>0.05$ ), while RE at -0.0844 was a significant model $(\mathrm{p}<0.05)$.

The adjusted R-square shows the ability to explain the effect of the PC and CI variables (which have been corrected by error standard) on the PG. The value of the adjusted R-square obtained was $0.6224>0.5$ which means it was strong (Sudjana, 2005). The F-statistic describes the simultaneous effect of the independent variables (PC and CI) on PG. The F value obtained was 212.2919 and significant $(p<0.05)$, indicating that this model can be used to predict the dependent variable (PG).

\section{Model Accuracy and the Contribution of PC and CI}

To obtain an appropriate estimation model, the $\mathrm{CE}$, FE, or RE models need to be tested using the Chowtest, Hausman test, and ML test (Tab. II).

From the Chowtest, the cross-section value obtained was F $49.005<0.05$, which means that the FE model was more precise than the CE model. The Hausman test obtained a random cross-section value of $1.01128>0.05$. According to the criteria above (Tab. II), this means that the RE model was more appropriate than the FE model. The Lagrange Multiplier (ML) test obtained LM 277.409, which was significant $(p<0.05)$, meaning that the RE model was more precise than the CE model. The overall results of this test indicated that the RE model was more precise than the CE and FE models. Thus, there was a strong reason to set the RE model as an appropriate estimation model, as described in Tab. III.
From Tab. III, the F-statistic obtained was 20.0602 $(p<0.05)$, showing that PC and CI simultaneously had a significant influence on PG. The t-statistic values show the coefficients and partial effects of each individual, including the intercept. The results showed that the intercept value of 5.6632 was significant ( $\mathrm{p}<0.05)$, PC 0.0036 was not significant ( $p>0.05)$, and the PC of -0.0284 was a significant $(p>0.05)$ value of PG. Thus, the equation of the RE estimation model can be written as follows:

$P G=5.6632+0.0032 P C-0.0284 C I$.

Equation (6) shows that PC contributes positively to the PG of 0.0032 . It can be interpreted that every $1 \%$ increase in the number of PC contributes to an increase in PG of $0.0032 \%$ and vice versa. However, despite its small enough value, statistically, it is also significant. CI contributed negatively and significantly to a PG of -0.0284 . Each increment, a $1 \% \mathrm{CI}$ extension, contributes to a $0.0284 \%$ decline in PG. In contrast, any decrease of $1 \%$ CI means a $0.0284 \%$ contribution to PG increase.

\section{Shortening}

The average value of CI observations over the last 5 years (2012-2016) reached 28.18 months. In other words, the length of time it takes for a PC from first birth to the next delivery is 28.18 months. This time is too long, so CI contributes negatively $(-0.0284)$ to the PG of beef cattle in Indonesia. For every $1 \%$ increase (renewal), the CI decreases the PG contribution by $0.0284 \%$; on the contrary, a $1 \%$ decline in CI will increase the population growth (PG) by $0.0284 \%$. Therefore, to increase PG, it is advisable to support the effort to shorten the CI. On that basis, we simulate and try to project the

III: The chosen estimation Model, RE

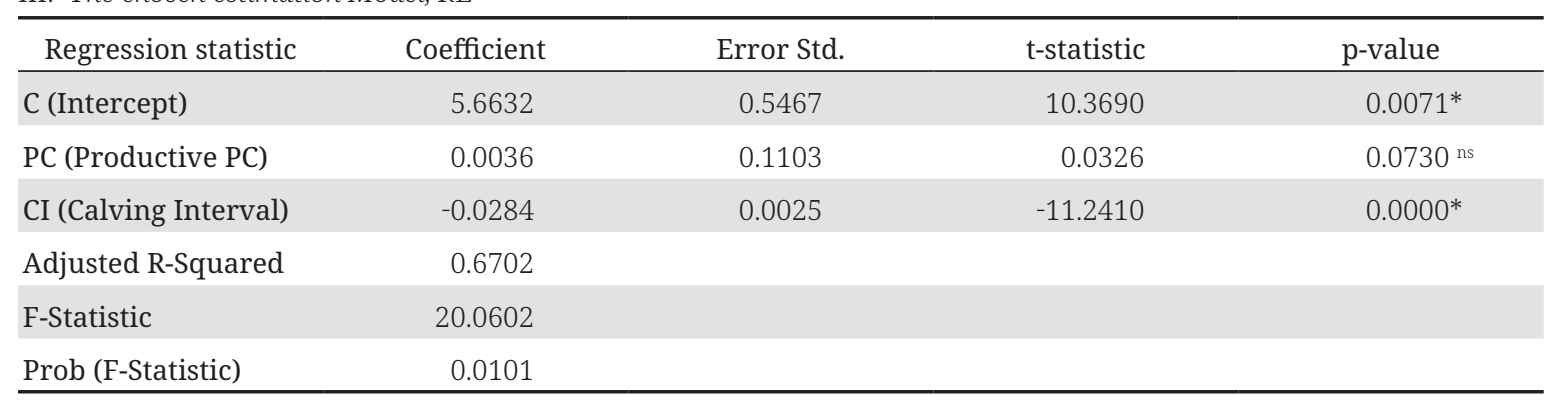

note: mark * means significant on $5 \%$ level ( $p<0.05)$, ns = not significant

Significant means that the value of sample can be generalized to the population 
IV: Shortening of CI and its Contribution to PG Changes

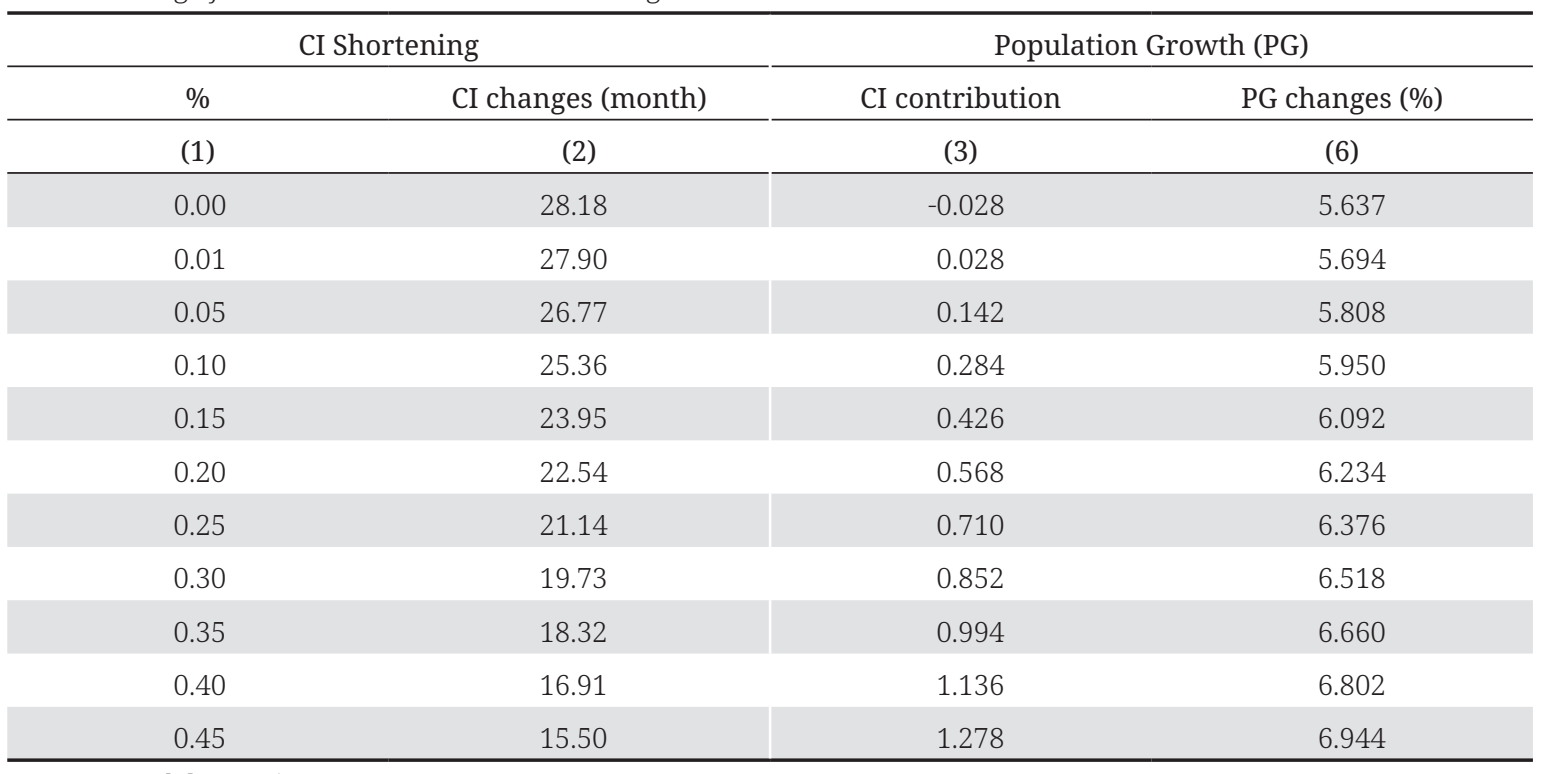

Note PG model equation $=5.663+0.003 \mathrm{PC}-0.0284 \mathrm{CI}$

shortening of CI from 28.18 to 15.5 months, by $45 \%$ (Tab. IV).

Tab. IV column (1) describes a CI shortening ranging from $0.00 \%$ (without shortening) to $45 \%$. Column (2) is the amount of shortening in units of 'month', column (3) is the contribution of the CI in each percentage of the shortening. Columns (4) and (5) are the fixed values of the PC coefficients and intercept (C) of the estimation models. Column (6) is the change in PG (\%) as the effect of each CI shortening.

Without shortening (0.00\%), the CI length remained 28.18 months, showing a negative CI contribution (-0.028) so that PG decreased from $5.663 \%$ to $5.637 \%$. The shortening of CI by
5\% makes the calving (birthing) period shorter (26.77 months). The CI contribution increased to $0.142 \%$ and increased PG to $5.808 \%$, and so on until it is possible to shorten CI to $45 \%$ (15.5 months) and increase PG to 6.944\% per year

Fig. 1 presents three CI conditions, i.e. CI 13 'very satisfactory', CI 15.5 months 'satisfactory' and CI 28.18 'very unsatisfactory'. Here CI is divided into three periods. The pregnant period, which is 9 months, is the same for all three conditions. Weaning and mating periods are grouped into different periods. The intention is to show that the length of the CI is greatly dependent on the period of cattle mating.

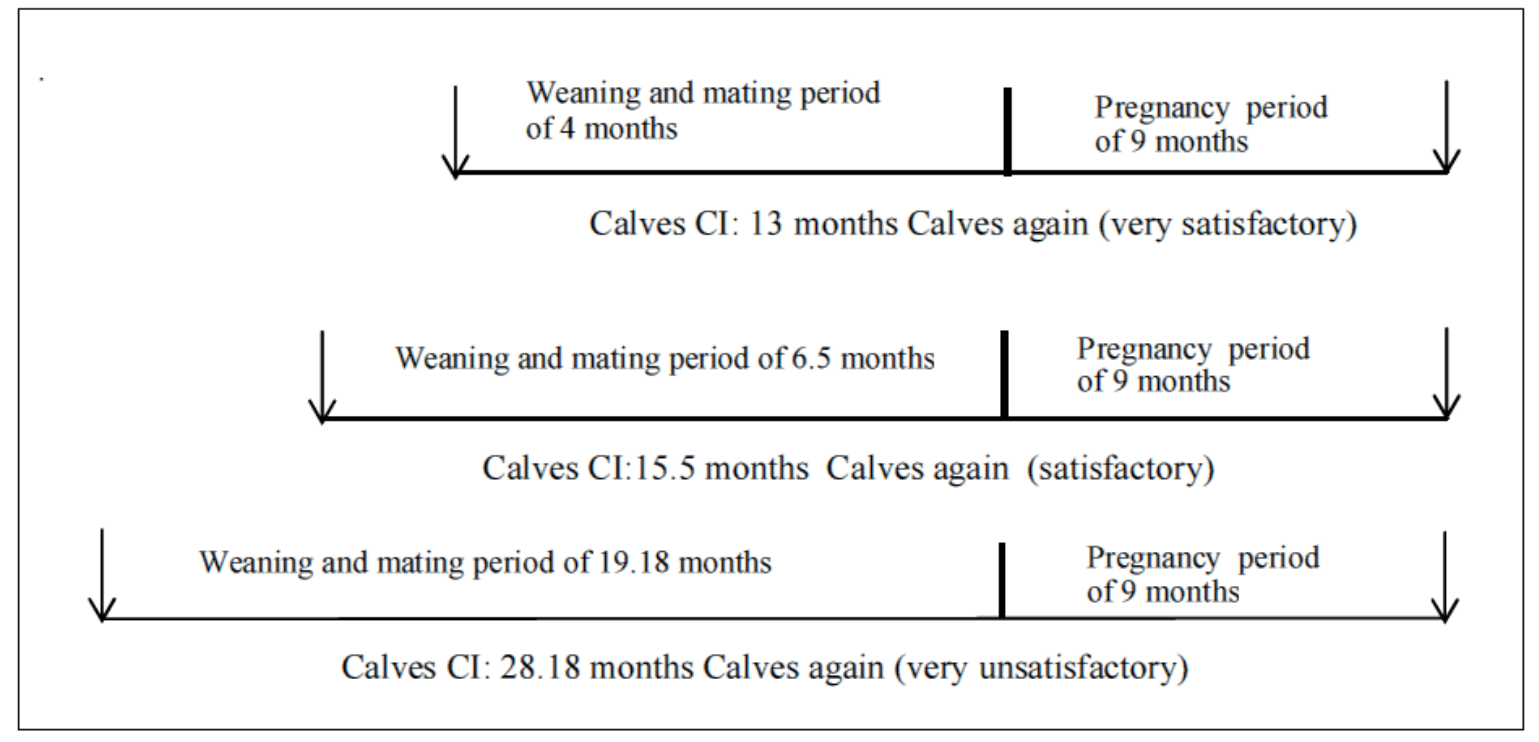

1: The difference between the three CI conditions 


\section{DISCUSSION}

\section{The Accuracy of the Estimation Model}

The appropriate estimation model is the RE model according to the Chowtest, Hausmantest and LM test rejection criteria (Tab. II). This result is in line with research conducted by Gujarati (2012), Ekananda (2014), Sarwono and Hendra (2014) and Widarjono (2016). These experts have advocated the selection of appropriate models through the use of these three tests.

The assumption of the $\mathrm{CE}$ and $\mathrm{FE}$ shortcut model is not a consideration in the proper model selection. Nevertheless, it is worth discussing the assumption of CE and FE as unlabeled models. The CE model builds the assumption that both the intercept $\left(\beta_{0}\right)$ and the slope $\left(\beta_{1}\right)$ are inter-district and between times during fixed observation (cash). This assumption is clearly far from the reality. In cattle farms in Indonesia, the characteristics between provinces/regions are distinctly different, ranging from the type of forage (feed) available to the maintenance system, as determined by the traditions and culture of different breeders in each region. This reason is in line with the findings of Ibrahim et al. (2013), Bettencourt et al. (2015), and Kemi (2016), who have reported that the factors of tradition and culture systems affect livestockkeeping and production systems.

The FE model assumes that the slope $\left(\beta_{1}\right)$ remains, but the intercept $\left(\beta_{0}\right)$ between regions and between times is different. This assumption has acknowledged that inter-regional differences are closely related to tradition and culture systems. However, the assumed slope $\left.\beta_{1}\right)$ remains, as if negating the possibility of a positive development or a negative disturbance to PC and CI during the observation. RE assumes that every district has different intercept $\left(\beta_{0}\right)$ as the random variable or stochastick. This RE also calculates the error that is possible to correlate with cross-section and timeseries.

The slope is a value that shows the extent of the contribution given by a free variable to the response variable (Abrevaya and Shen, 2014; Widarjono, 2016). In this study, the slope can be interpreted as the average of changes that occurs in PG in response to any increase or decrease in PC and/or CI units. This assumption is also less realistic because every year there is an increase and/or decrease in the number of PCs and the CI spacing. An increase in PCs occurs every year from the number of PC which was previously under 2 years old, and the next year is over 2 years old. Meanwhile, a decline in the number of PCs can occur due to rampant cuts, or because they become non-productive again after reaching the age of 7 years. This reason is supported by livestock data in the figures for 2016 (BPS 2016b). Changes in CI also take place every year in line with the increasing PC life. This is in line with the findings of Werth et al. (1996) and Changhee et al. (2013) that the age of PC has a significant effect on the CI spacing.

\section{PC and CI Contribution}

Equation (6) shows that PC contributed positively to PG by a 0.0032 increase per annum but was not significant ( $p>0.05$ ), while CI contributed negatively by a -0.0284 increase per annum and was significant $(p<0.05)$. Significant means that the statistical value that occurs in the sample data can also be applied to the population data so that it can be generalized (Sudjana, 2005; Sugiyono, 2009). Thus, the findings of this study can also be generalized, at least for the territory of Indonesia, that the growth (increase or decrease) of the beef cattle population in Indonesia is significantly influenced by CI.

The results of this study reinforce the findings of previous researchers (Sada, 1968; Flores, 1971; Bourdon and Brinks, 1983; Larsson and Berglund, 2008; Grossi et al., 2016) stating that CI is one of the main factors contributing to population growth in beef production. Also, it is almost (approximately) in line with the findings of Olmo et al. (2016) from Cambodia and Ibragimov (2016) from Malaysia. Both reported that the cause of the decline in the beef cattle population in rural Cambodia in the years 2009-2013 and in Malaysia was due to reproductive factors. Although neither work mentions CI as one of the causes, we can understand that $\mathrm{CI}$ is one of the livestock reproduction indicators.

The findings of this study were not in agreement with Lole et al. (2013) and Isyanto and Iwan (2016). Both researchers reported that the growth of the beef cattle population in East Nusa Tenggara (NTT) and in Ciamis, West Java, Indonesia, was influenced by the high number of culling and the conversion (reduction) of pastoral land into plantation and settlement land.

A high culling rate is an autonomous variable, occurring outside the domain of livestock production. It is more related to population growth, income, and appetite. It is, therefore, perhaps wiser to question the growth of populations within the livestock domain. And when we are investigating the population growth, it will include productive factor, of which CI is an indicator.

The link between population growth and the reduction of pasture land relates more to forage feeding. The phenomenon of the slowing population growth in Indonesia is not only in areas that are reducing shrimp farms but also in other areas that still have large grazing lands such as Sulawesi, Kalimantan and Maluku (BPS 2016b). The findings of Lole et al. (2014) may apply to NTT (East Nusa Tenggara) but not to the whole of Indonesia. Nevertheless, the efforts of scientific investigation in this area is valuable. 


\section{Shortening CI and Implication}

The CI shortening issue is based on the findings of this study, in which CI contributes negatively, or tends to decrease PG. This study supports the findings of Han et al. (2016) from China, which concluded that the key scenario for increasing calfcrop production is CI shortening.

Fig. 1 demostrates that if a 13-month CI was wanted, it was advisable for conception to occur no later than 4 months after delivery. After a 2-month calf, a normal cycle of oestrus began to appear, allowing the cycles to occur 2-3 times, so the failure of conception in the first cycle of oestrus can be repeated in the second and third cycle of oestrus. In Indonesia, the 13-month CI is found in dairy PC whose maintenance systems are intensive, as some researchers have previously reported, such as Pramono and Hari (2008) in Yogyakarta, Prasetyoi (2015) in Batu Raden Central Java, Zainuddin et al. (2015) in Malang East Java, Reswati et al. (2015) in Sumatera Barat, Popescu (2014) in Romania and most recently Catalin (2017) in Romania.

If the program fell within the CI of 15.5 months (Fig. 1), then the conception or beginning of pregnancy should occur no later than 6 months after the first (previous) birth. During these six months, there was a period of weaning and mating (service period). If weaning took 2-3 months, then there remains 3-4 months of the service period. In this 3-4 months period, normal PCs will experience cycles of oestrus (estrus) as many as 4-5 times and these should be utilized optimally for mating. If conception does not occur in the first cycle of oestrus, there is still a second, third and so on. Thus, it is quite rational to shorten the CI from 28.18 to 15.5 months.

The CI of 28.18 months obtained from the results of this study was not conducive to PG, being in the category 'very unsatisfactory' (Sada, 1968). A bunting period that lasts an average of 9 months (Khan, 2017) leaves 18.18 months or 1.5 years more for the weaning and mating period. If the weaning period lasts 3 months, there are still 15.18 months left for mating (service period). This is too long a period for the purpose of farms that expect growth.

The duration of the PC lasts only about 5 years, from the age of 2 to 7 years. If the first mating took place successfully at the age of 2 years, then with a CI of 28.18 from this month, a PC only had the chance to give birth to 2 calves throughout its life cycle. This is a waste of growth resources and prevents farmers from getting a better income from calf-crop production. This condition brings many problems, such as the ever-increasing need for meat from production, vulnerable food security, prolonged imports, high meat prices, and inflation. By contrast, when the value of $\mathrm{CI}$ is below 28.18 months, for example, 20 months, then a PC has the opportunity to give birth to 3 calves in the life cycle.

\section{CONCLUSION}

The results show that the shortening of the calving interval (CI) could increase population growth. Each 1\% decline in CI from 28.18 to 27.90 months gave an additional contribution to the population growth (PG) of $0.031 \%$ from $5.663 \%$ to $5.694 \%$. Without CI shortening, PG decreases. The shortening of CI in cattle farms in Indonesia could be done by up to 45\% from 28.18 to 15.15 months and contribute to a PG of $1.281 \%$ from $5.633 \%$ to $6.944 \%$.

The key to CI shortening is a semi-intensive system change and control of the mating process. That is, breeders should introduce time restrictions in weaning periods and maximize the conception of the mating period (service period).

\section{Acknowledgements}

The writer would like to thank the Animal Husbandry and Animal Health Office of South Sulawesi Province for providing data and information when the research was conducted. Big gratitude is also addressed to Institute for Research and Community Service (LP2M) Alauddin Makassar State Islamic University which provides support in the process of writing this journal. Also, a big gratitude is also addressed to Catur Sugiyanto, Professor, and Director of Master of Science and Doctorate Study Program of Faculty of Economics and Business, Gajah Mada University for valuable suggestions and improvement of this paper. The entire contents of this paper are the responsibility of the writer.

\section{REFERENCES}

ABREVAYA, J. and SHEN, S. 2014. Estimation of censored panel-data models with slope heterogeneity. J. Appl. Econ., 29(4): 523-548.

BADAN PUSAT STATISTIK. 2016a. Statistical Yearbooks of Indonesia 2015. Sub-Directorate of Statistical Compilation and Publication. Jakarta: BPS-Statistics Indonesia. 
BADAN PUSAT STATISTIK. 2016b. Farms In Figures 2016 [in Indonesian: Peternakan dalam Angka 2016]. Jakarta: BPS-Statistics Indonesia.

BADAN PUSAT STATISTIK. 2016c. Agricultural Producer Price Statistics of Livestock and Fishery Subsector 2016 [in Indonesian: Statistik Harga Produsen Pertanian Subsektor Peternakan dan Perikanan 2016]. Jakarta: BPS-Statistics Indonesia.

BETTENCOURT, E. M. V., TILMAN, M., NARCISO, V., CARVALHO, M. L. D. S. and HENRIQUES, P. D. D. S. 2015. The livestock roles in the wellbeing of rural communities of Timor-Leste. Rev. Econ. Sociol. Rural., 53(1): 63-80.

BOURDON, R. M. and BRINKS, J. S. 1983. Calving date versus calving interval as a reproductive measure in beef cattle. J. Anim. Sci., 57(6): 412-1417.

BUNMEE, T., CHAIWANG, N., KAEWKOT, C. and JATURASITHA, S. 2018. Current situation and future prospects for beef production in Thailand - A review. Asian-Australasian Journal of Animal Sciences (AJAS) 2017, 31(7): 968-975.

DO, C., WASANA, N., CHO, K., CHOI, Y., CHOI, T., PARK, B. and LEE, D. 2013. The effect of age at first calving and calving interval on productive life and lifetime profit in Korean Holsteins. AsianAustralas J. Anim. Sci., 26(11): 1511-1517.

EKANANDAN, M. 2014. Analysis of Econometrics Data Panel [in Indonesian: Analisis Ekonometrika Data Panel]. Jakarta: Mitra Wacana Media.

FLORES, A. G. 1971. A study of calving interval Retrospective. Dissertation Thesis. Iowa State University, Iowa.

GODBER, O. F. and WALL, R. 2014. Livestock and food security: vulnerability to population growth and climate change. Glob. Change Biol., 20(10): 3092-3102.

GROSSI, D. A., BERTON, M. P., BUZANSKAS, M. E., CHUD, T. C., GRUPIONI, N. V., DE PAZ, C. C., LÔBO R. B. and MUNARI, D. P. 2016. Genetic analysis on accumulated productivity and calving intervals in Nelore cattle. Trop. Anim. Health Prod., 48(1): 207-210.

GUJARATI D. N. 2012. Basics of Econometrics Part 2 [in Indonesian: Dasar-Dasar Ekonometrika Buku 2], $5^{\text {th }}$ Edition. Salemba Empat, Jakarta.

HAN, X. P., HUBBERT, B., HUBBERT, M. E. and REINHARDT, C. D.2016. Overview of the beef cattle industry in China: the widening deficit between demand and output in a vicious circle. J. Fisheries Livest. Prod., 4: 190.

HUYEN, L. T. T., HEROLD, P., MARKEMANN, A. and VALLE ZÁRATE, A. 2011. Resource use, cattle performance and output patterns on different farm types in a mountainous province of northern Vietnam. Animal Production Science, 51(7): 650-661.

IBRAGIMOV, A., ARSHAD, F. M., BALA, B. K., BACH, N. L. and MOHAMMADI, S. 2016. Management of beef cattle production in Malaysia: a step forward to sustainability. Am. J. Appl. Sci., 13(9): 976-983.

IBRAHIM, A. S., SHIWEI, X. and WEN, Y. 2013. The Impact of social factors of rural households on livestock production and rural household income in White Nile State of Sudan International. J. Agric. Food Res., 2(4): 1-13.

IFAR, A. and BAMBANG, N. 2010. Proceeding Potential and Prospect of Beef Cattle Business in Eastern Indonesia (KTI) in the Framework of Development of Integrated Economic Zone (KAPET) [in Indonesian: Potensi dan Prospek Usaha Peternakan Sapi Potong di Kawasan Timur Indonesia (KTI) Dalam Kerangka Pengembangan Kawasan Ekonomi Terpadu (KAPET)]. In: Semiloka Strategi Pengembangan KAPET di Kawasan Timur Indonesia dalam Menghadapi Era Global. 5-6 Juli 2010. Malang: Brawijaya University.

ISYANTO, A. Y. and IWAN, S. 2016. Factors Influencing Population of Beef Cattle in Ciamis Regency, West Java Province, Indonesia. J. Econom. Sustain. Develop., 7(22): 33-38.

KEMI, A. O. 2016. Economic impact of livestock production on the Society: A case study of Ikare Akoko Ondo State. IOSR J. Agric. Veteri. Sci., 9(12): 77-80.

KHAN, S. 2017. Study of gestation period, calving interval and birth weight of achai cattle at livestock research and development station Dir Lower, Pakistan. Biol. Agric. Healthcare, 7(9): 12-15.

LARSSON, B. and BERGLUND, B. 2008, Reproductive performance in PC with extended calving interval. Reprod. Domes. Anim., 35(6): 277-279.

LIVESTOCK AND ANIMAL HEALTH STATISTICS. 2015. Directorate General of Animal Husbandry and Animal Health Ministry of Agriculture Indonesia [in Indonesian: Direktorat Jenderal Peternakan dan Kesehatan Hewan Kementerian Pertanian RI]. Available at: http://ditjenpkh.pertanian. go.idaccessedon 12 Agustus 2016 [Accessed: 2019, July].

LOLE, U. R., HARTOYO, S., KUNTJORO and RUSASTRA, I. W. 2013. Analysis of regional distribution capacity and priorities for improving beef cattle population in East Nusa Tenggara Province. Media Peternakan, 36(1): 70-78. 
MANEA, C. R. 2017. The Assessment of the calving interval at PC in the mountain area. Ann. Valahia University of Targoviste., 11(1): 14-22.

OLMO, L., ASHLEY, K., YOUNG, J. R., SUON, S., THOMSON, P. C., WINDSOR, P. A. and BUSH, R. D. 2016. Improving smallholder cattle reproductive efficiency in Cambodia to address expanding regional beef demand. Trop. Anim. Health Prod., 49(1): 163-172.

POPESCU, A. 2014. Research on the influence of the calving interval on milk yield. scientific papers series management. Econ. Eng. Agric. Rural Dev., 14(1): 291-296.

PRAMONO, A., KUSTONO and HARTIADI, H. 2008. Calving dairy intervals in the Special Region of Yogyakarta in terms of reproductive performance [in Indonesian: Calving interval sapi perah di Daerah Istimewa Yogyakarta ditinjau dari kinerja reproduksi]. Buletin Peternakan, 32(1): 38-50.

PRASETIYO, Y., HARTONO, M. and SISWANTO. 2015. Calving interval of lactation dairy cattle at Great Hall of Breeding of Superior Livestock and Forage of Forage (BBPTU-HPT) Baturraden Purwokerto, Central Java [in Indonesian: Calving interval sapi perah laktasi di Balai Besar Pembibitan Ternak Unggul Dan Hijauan Pakan Tenak (BBPTU-HPT) Baturraden Purwokerto, Jawa Tengah]. Jurnal Ilmiah Peternakan Terpadu, 3(1): 7-14.

PRIYANTO, D. 2011. The business development strategy is cut into supporting the self-sufficiency program of beef and buffalo in 2014 [in Indonesian: Strategi pengembangan usaha ternaksapi potong dalam mendukung program swasembada daging sapi dan kerbau tahun 2014]. Jurnal Litbang Pertanian, 30(3): 308-116.

RASMINATI, N., UTOMO, S. and RIYADI, D. A. 2010. Cutting productive female cattle in slaughterhouses in Yogyakarta Special Region [in Indonesian: Pemotongan sapi betina produktif di rumah potong hewan di Daerah Istimewa Yogyakarta]. Sains Peternakan, 7(1): 20-24.

RESWATI, J. and NURDIN, E. 2014. Performance of dairy cattle reproduction in West Sumatra [Performa reproduksi sapi perah di Sumatera Barat]. Jurnal Peternakan Indonesia, 16(3): 157-165.

SADA, I. 1968. The length of the gestation period, calving interval and service period in indigenous West African cattle: N’Dama, West African Shorthorn and Sokoto Gudale. Ghana J. Agric. Sci., 1: 9197.

SARWONO, J. and HENDRA, N. S. 2010. Eviews: How to Operate and Analyze Procedures[in Indonesian: Eviews: Cara Operasi dan Prosedur Analisis]. Yogyakarta: ANDI.

SOEJOSOPOETRO, B. 2011. Study of the productive female cattle slaughtering in RPH Malang [in Indonesian: Studi tentang pemotongan sapi betina produktif di RPH Malang]. Ternak Tropika, 12(1): 22-26.

SUARDANA, I. W., SUKADA, I. M., SUADA, I. K. and WIDIASIH, D. A. 2013. The analysis of amount and various age of productive female Bali cattle slaughtered at abbatoirs. Jurnal Sain Veteriner, 31(1): 43-48.

SUDJANA. 2005. Metode Statistika. Bandung: Tarsito.

SUGIYONO. 2009. Statistika untuk Penelitian. Bandung: Alfabeta.

UNDANG-UNDANG REPUBLIK INDONESIA. 2014. Law of the Republic of Indonesia Number 41 Year 2014 About Amendment To Law Number 18 Year 2009 About Animal Husbandry and Animal Health. State Sheet No. 5619 [in Indonesian: Undang-Undang Republik Indonesia Nomor 41 Tahun 2014 Tentang Perubahan Atas Undang-Undang Nomor 18 Tahun 2009 Tentang Peternakan dan Kesehatan Hewan. Lembar Negara Nomor 5619].

WERTH, L. A., AZZAM, S. M. and KINDER, J. E. 1996. Calving intervals in beef PC at 2, 3, and 4 years of age when breeding is not restricted after calving. J. Anim. Sci., 74(3): 593-596.

WIDARJONO, A. 2016. Econometrics: Introduction and Application With Eviews Guide [in Indonesian: Ekonometrika: Pengantar dan Aplikasi Disertai Panduan Eviews]. Yogyakarta: UPT STIM YKPN.

WIGUNA, I. W. A., NI WAYAN, T. I., PASARIBU, S., INDRASTI, R., KUSUMA, N., BUDIANA, N. and WIDIANTA, M. 2015. Efforts to Overcome Cutting of Productive Cattle in Supporting Sustainable Cattle Beef In Bali [in Indonesian: Upaya Mengatasi Pemotongan Sapi Betina Produktive Dalam Mendukung Swasembada Daging Sapi Berkelanjutan Di Bali]. Bali: Balai Pengkajian Teknologi Pertanian Bali.

ZAINUDIN, N. I. and SUYADI. 2015. Efficiency of PFH dairy reproduction at various age in CV. Milkindo Berka Abadi Tegalsari Village, Kepanjen Sub-district, Malang Regency [in Indonesian: Efisiensi reproduksi sapi perah PFH pada berbagai umur di CV. Milkindo Berka Abadi Desa Tegalsari Kecamatan Kepanjen Kabupaten Malang]. Jurnal Ilmu-Ilmu Peternakan, 24(3): 32-37. 